\title{
ADOLESCENCE: RISK FACTORS FOR PRECANCEROUS LESIONS AND CERVICAL CANCER AND PREVENTION METHODS
}

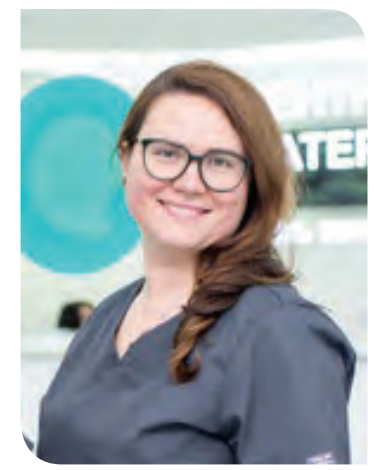

N.K. SILINA

$\mathrm{PhD}$, senior researcher, Department of Medical and Psycho-Social Problems of Family Health, Institute of

Pediatrics, Obstetrics and Gynecology of the NAMS of Ukraine

Contacts:

N.N. Silina

Institute of Pediatrics, Obstetrics and Gynecology of NAMS of Ukraine, Department of Medical and Psycho-Social Problems 04050, Kyiv, Manuilskogo, 8 tel.: +38 (044) 4838067 e-mail: dr.silina@gmail.com

\section{INTRODUCTION}

Adolescence - is one of the critical periods of life, characterized by rapid growth rate and changes that can be compared only to those that happens in infant age. The duration and characteristics of this period depends on the time, culture and socio-economic situation. Over the last century adolescence passed through numerous significant changes like the earlier onset of puberty, a delayed age of marriage, urbanization, global communication and changes in sexual relationships and behaviors. It's time when teens get «adult» experience. This age really relates to the formation of "risky behavior» and requires close attention not only from parents of teenagers, but schools and society in general [1].

Many teenagers face the pressure of circumstances under which start to use alcohol, cigarettes or drugs and enter into sexual relationships at an early age, putting themselves at risk of injury, unwanted pregnancies and sexually transmitted diseases (STDs). Risk sexual behavior, or vice versa, teenager firm belief in the need to abstain from early sexual activity, drug substance use or correct way of life may have long-term positive or negative impact on health and well-being in the future. Therefore, at this age adults have unique opportunities to use measures that help teenagers on the formation of preserving behavior [1].

In Ukraine, for reasons of deep demographic crisis the problem of reproductive health of adolescents gained special significance. Research analysis demonstrates that sexual behavior of

TABLE 1. THE AVERAGE AGE OF FIRST SEXUAL DEBUT

\begin{tabular}{|c|c|c|c|}
\hline & Boys & Girls & All \\
\hline Intermedium, $\boldsymbol{n}$ & 14,7 & 15,1 & 14,9 \\
\hline Median, $\boldsymbol{n}$ & 15 & 15 & 15 \\
\hline Minimal, $\boldsymbol{n}$ & 12 & 13 & 12 \\
\hline Maximum, $\boldsymbol{n}$ & 17 & 16 & 17 \\
\hline Didn't answer, $\boldsymbol{n}(\%)$ & $4(10,5)$ & $4(18,2)$ & $8(13,3)$ \\
\hline
\end{tabular}

TABLE 2. AMONG THOSE WHO HAD SEXUAL EXPERIENCE, IN THIS PERIOD HAVE SEX

\begin{tabular}{|c|c|c|c|}
\hline & Boys & Girls & All \\
\hline No, n (\%) & $5(13,2)$ & $9(40,9)$ & $14(23,3)$ \\
\hline Sometimes, $n(\%)$ & $23(60,5)$ & $7(31,8)$ & $30(50,0)$ \\
\hline Often, $n(\%)$ & $7(18,4)$ & $4(18,2)$ & $11(18,3)$ \\
\hline Constantly, $n(\%)$ & $3(7,9)$ & $1(4,5)$ & $4(6,7)$ \\
\hline Didn`t answer, $n(\%)$ & $0(0)$ & $1(4,5)$ & $1(1,7)$ \\
\hline All, $n(\%)$ & $38(100,0)$ & $22(100,0)$ & $60(100,0)$ \\
\hline
\end{tabular}

young people in Ukraine has undergone significant changes and is characterized by a relaxed attitude to sex issues. This is evidenced by the ubiquity of premarital sex, lowering the age of sexual debut, frequent change of sexual partners, and the annual growth of unwanted pregnancy. Some studies show that young people who lead active sexual life, loyal to include the possibility of sex with a casual partner and to pre- and extramarital sexual relations [2].

\section{ANALYSIS OF PUBLISHED DATA}

Analysis of previous data on adolescent sexual development and knowledge of human papilloma virus (HPV) in a survey of participants cohort study «Family and Children of Ukraine» in Dneprodzerzhinsk that was hold by the Department of medical and psycho-social health problems of the family (Institute of Pediatrics, Obstetrics and Gynecology of the NAMS of Ukraine) where 474 answers were analyzed from 1072 survey data, namely, 239 (50,4\%) males and 235 (49,6\%) girls (mean age of respondents was 16,2 years) showed that the average age of first sexual intercourse among adolescent girls averaged 15,1 years, for boys 14,7 [3]. Among the group of adolescents with sexual experience $18 \%$ have sex often and almost $32 \%$ sometimes (table 1, 2).

According to the survey, most teenagers who answered the question believed that the best age for onset of sexual activity in boys and girls age is $16-18$ years. Only $13,4 \%$ of respondents reported that sexual debut is optimal married [3].

So the increase of premarital sexual relations on the one hand is evidence of "liberalization" of sexual rules of today's youth, and on the other side quite dwells upon the prevention of unwanted pregnancy and transmission STDs during sexual intercourse [1].

Disastrous growth cases of STDs among adolescents and young people with a risky way of life (alcohol and drug use, smoking) - is a serious threat for the sexual and reproductive health. Of particular concern is the health of adolescent girls. In addition to unstable immune system, STDs, one in three teenage girls, who have regular sexual life, faces the emergence of an unwanted pregnancy. Therefore, the growth of teenage abortions and STDs significantly impair the reproductive health of adolescent girls and create conditions for the deterioration of reproductive health [2]. 
All these factors form favorable background for the rapid increase of the cervical cancer and precancerous lesions in the young age group. In Ukraine, each year more than 5000 cases of cervical cancer are being registered, $50 \%$ of women who are getting sick - woman of reproductive age. Every day in our country 6 women die from cervical cancer [4].

According to the research made by the Institute of Medical Family Problems of the Donetsk State Medical University named after Maxim Gorky, incidence of cervical pathology in sexually active adolescent girls is $71,37 \%$. Cervical intraepithelial neoplasia (CIN) and cervical cancer at this age group was diagnosed in $25,83 \%$ of case, while literature data shows that the percentage does not exceed $17-20 \%$.

It was proved that the factors that contribute to the development of cervical pathology in sexually active adolescent girls is risky sexual behavior, STDs, estrogen-progesterone violation of equilibrium and unstable immune system.

It was established that girls with CIN had listed below conditions in significantly more frequent cases were observed [2]:

5 sexual debut at 16 years $-1,6$ times;

a multiple sexual partners - 1,2 times;

a history of abortion - 2,3 times;

menarche to 12 years $-1,4$ times;

the presence of chlamydial infection - 1,7 times;

3 the presence of herpes infection - in 2,0 times;

s long inflammatory disease of the uterus - 1,5 times;

hyperpolymenorrhea-1,9 times;

3 the presence of acyclic bleeding - 3,2 times;

5 prevalence of ectopic epithelium to the II-III zone - 2,9 times;

- the average level of estradiol in these age group was also significantly higher $-2,5$ times $(p<0,05)$.

These differences allowed considering these indicators as main risk factors for $\mathrm{CIN}$ and cervical cancer in sexually active adolescent girls.

HPV is a proven cause of precancerous lesions and cervical cancer (CC). HPV was detected in $99.7 \%$ of the biopsies of squamous cell cervical cancer [10].

There are more than $100 \mathrm{HPV}$ genotypes. At least 30 types of HPV are able to infect the genital tract mucosa and 15 HPV types are classified as oncogenic (high-risk genotypes) [6]. HPV genotypes 16 and 18 are the cause of approximately $70 \%$ of all cases of invasive cervical cancer worldwide, with genotype 16 has the highest oncogenic potential. The next highest prevalence of oncogenic HPV is genotypes 45,31 and 33 , which cumulatively lead to an additional $~ 10 \%$ of cases of cancer in the world [5] (figure).

Methods of prevention of precancerous lesions and cervical cancer can be divided into primary - vaccination and secondary - cervical screening. Today worldwide vaccination against HPV is considered a breakthrough of the 21st century in the prevention of cervical cancer. Realizing the seriousness of the CC problem and other diseases caused by HPV, the international system of public health, WHO recommends to include routine HPV vaccination into national immunization program [6].

In Ukraine vaccination against infection caused by HPV regulated by the Order of the Ministry of Health of Ukraine № 595 from 16.09.2011 and refers to "Recommended vaccinations" [6].

WHO recommends girls ages $9-10$ to 13 years as the primary target group for vaccination. The age of the target group for

\section{2\% OF CERVICAL CANCER CASES ARE CAUSED 5 TYPES OF HPV ONCOGENES}

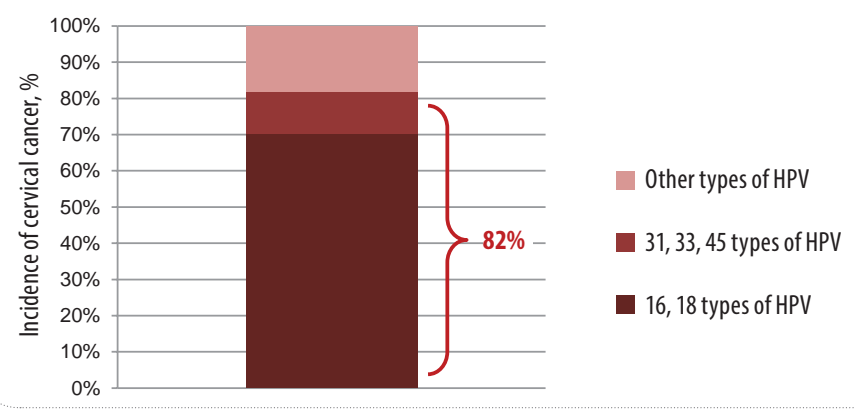

FIGURE. CASES OF CERVICAL CANCER, DEPENDING ON THE TYPE OF HPV

vaccination was chosen by WHO because of the data of age sexual debute and possible vaccination coverage among adolescent girls in schools, health facilities and local community organizations. And it was proved that vaccination is the most effective before the sexual activity [6].

Now days the antivacinal company is getting more and more aggressive among adults, our reach on this topic showed very positive moment especially in the girls group. Only $13,3 \%$ of adolescence girls strictly refuse to make vaccination against HPV (table 3).

\begin{tabular}{|c|c|c|c|}
\hline \multicolumn{4}{|c|}{ TABLE 3. DO YOU AGREE TO VACCINATE YOURSELF AGAINST HPV? } \\
\hline Yes, $n(\%)$ & Boys & Girls & All \\
\hline Didn`t decide yet, $n(\%)$ & $22(12,1)$ & $11(18,3)$ & $15(16,1)$ \\
\hline Strongly disagree, $n(\%)$ & $6(18,2)$ & $39(65,0)$ & $61(65,6)$ \\
\hline Didn`t answer, $n(\%)$ & $1(3,0)$ & $8(13,3)$ & $14(15,1)$ \\
\hline All, $n(\%)$ & $33(100,0)$ & $60(100,0)$ & $3(3,2)$ \\
\hline
\end{tabular}

Teens have free access to a variety of media, especially the Internet, so consider themselves sufficiently knowledgeable in the subject of sexuality and its consequences. We ve also found out the most popular resources of information among teens on the topic of sexual relations (table 4). Girls mostly get information from books, magazines and their mothers. Boys mostly get information on the topic of sexual relationship from their friends, internet, TV.

\begin{tabular}{|c|c|c|c|c|}
\hline & Boys & Girls & All & p \\
\hline $\begin{array}{l}\text { Books, newspapers, } \\
\text { magazines }\end{array}$ & $92(38,5)$ & $153(65,1)$ & $245(51,7)$ & 0,000 \\
\hline TV, films & $179(74,9)$ & $155(66,0)$ & $334(70,5)$ & 0,033 \\
\hline Friends & $148(61,9)$ & $144(61,3)$ & $292(61,6)$ & 0,885 \\
\hline Elder people & $88(36,8)$ & $94(40,0)$ & $182(38,4)$ & 0,477 \\
\hline Mother & $121(50,6)$ & $147(62,6)$ & $268(56,5)$ & 0,009 \\
\hline Father & $84(35,1)$ & $52(22,1)$ & $136(28,7)$ & 0,002 \\
\hline Teacher, psychologist & $75(31,4)$ & $89(37,9)$ & $164(34,6)$ & 0,137 \\
\hline Medical worker & $34(14,2)$ & $40(17,0)$ & $74(15,6)$ & 0,402 \\
\hline Brother/sister & $45(18,8)$ & $40(17,0)$ & $85(17,9)$ & 0,608 \\
\hline My sexual partner & $18(7,5)$ & $8(3,4)$ & $26(5,5)$ & 0,048 \\
\hline Internet & $118(49,4)$ & $112(47,7)$ & $230(48,5)$ & 0,709 \\
\hline
\end{tabular}

In real life, most young people do not know about the STD's because of unprotected sex, do not understand clearly transmission and have no idea of the consequences, opportunities for prevention and treatment [9]. 
TABLE 5. HAVE YOU EVER HEARD ABOUT HPV AND HPV-CAUSED DISEASES?

\begin{tabular}{|c|c|c|c|}
\hline & Boys & Girls & All \\
\hline Yes, $n(\%)$ & $33(13,9)$ & $60(25,5)$ & $93(19,6)$ \\
\hline No, $n(\%)$ & $177(74,1)$ & $157(66,8)$ & $334(70,5)$ \\
\hline Didn`t answer, $n(\%)$ & $29(12,1)$ & $18(7,7)$ & $47(9,9)$ \\
\hline All, $n(\%)$ & $239(100,0)$ & $235(100,0)$ & $474(100,0)$ \\
\hline
\end{tabular}

For example, the percentage of adolescents who are knowledgeable in matters of HPV and the disease it causes is about 20\% [3]. Girls in almost 10\% more knowledgeable than boys about HPV and its relationship with risk of cervical cancer (table 5).

Only $16 \%$ of teens who informed on HPV infections are agreeing

REFERENCES/ЛITEPATУPA

1. В03: Развитие подростков. Онлайн-ресурс.

[http://www.who.int/maternal_child_adolescent/topics/adolescence/dev/ru/index.html]

WHO: Adolescent development. Online. Last accessed March 19, 2015.

[http://www.who.int/maternal_child_adolescent/topics/adolescence/dev/ru/index.html] 2. Чайка, В.К.

Прогнозування та профілактика захворювань шийки матки у сексуально активних дівчатпідлітків / В.К. Чайка, І.І. Кравчук, І.К. Акимова // Педіатрія, акушерство та гінекологія. 2006. 一 № 6. - C. 62-65.

Chaika, V.K., Kravchuk, I.I., Akimova, I.K.

"Prediction and prevention of cervical diseases in sexually active adolescent girls." Pediatrics, Obstetrics and Gynecology, 6(2006): 62-65.

3. Річний звіт відділу медичних та психосоціальних проблем здоров'я сім'ї Інституту педіатрії, акушерства та гінекології НАМН України «Дослідити умови формування змін стану здоров'я дітей в процесі довготривалого їх спостереження та розробити заходи по його збереженню», 2011-2014 pp.

Annual report of the Department of Medical and Psycho-Social Problems of Family Health of the Institute of Pediatrics, Obstetrics and Gynecology of the NAMS of Ukraine

"Investigate the conditions of the children's health changes during long-term observation of and develop measures for its saving" (2011-2014).

4. Національний канцер-реєстр України, 2012 p

National Cancer Registry of Ukraine (2012).

5. Adapted from Parkin DM \& Bray F.

Vaccine, 3(24) (2006): 11-25. to undergo a course of vaccination against HPV. $15 \%$ of adolescents were strongly against vaccination and $65 \%$ undecided [3]. It was found that a greater percentage of girls were willing to take a vaccination against HPV compared with boys.

\section{CONCLUSIONS}

Thus the results showed that it is necessary to hold a powerful information campaign to inform teens and their families about healthy lifestyles, the formation of preserving health behavior and methods of modern global prevention of cancer through local social services, schools, health services health. Parents, social institutions, business structure and society in general are responsible for the formation of adolescent worldview healthy lifestyle.

6. Документ по позиции В03. Вакцины против вируса папилломы человека.

10 апреля 2009 г., №15, с. 117-132.

WHO position document. HPV vaccines.

April 10, 15(2009): 117-132.

7. Наказ М03 України № 595 від 16.09.2013 «Про порядок проведення профілактичних щеплень в Україні та контроль якості й обігу медичних імунобіологічних препаратів».

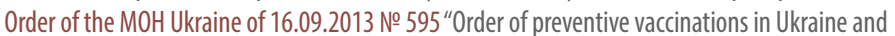
quality control and circulation of immunobiological medications."

8. Pedersen, $C$., et al.

J Adolesc Health, 40(2007): 564-571.

9. Анфілова, М.Р.

Соціальний портрет сучасного підлітка із захворюваннями, що передаються статевим шляхом / М.Р. Анфілова // Український журнал дерматології, венерології та косметології. — 2012. — № 3 (46). — C.144-147.

Anfilova, M.R.

"Social portrait of the modern teenager with sexually transmitted diseases." Ukrainian Journal of Dermatology, Venereology and Cosmetology, 3(46) (2012):144-147.

10. Walboomers, J.M.M., Jacobs, M.V., Manos, M.M., Bosch, F.X., Kummer, J.A., Shah, K. V., Snijders, P.J.F., Peto, J., Meijer, C.J.L.M. and Munoz, N.

"Human papillomavirus is a necessary cause of invasive cervical cancer worldwide." J Pathol, 189(1999): 12-19.

\section{ADOLESCENCE: RISK FACTORS FOR PRECANCEROUS LESIONS AND CERVICAL CANCER AND PREVENTION METHODS.}

N.K. Silina, senior researcher, Department of Medical and Psycho-Social Problems of Family Health, Institute of Pediatrics, Obstetrics and Gynecology of the NAMS of Ukraine Adolescence is a time of rapid growth and huge potential, but at the same time associated with the significant risks when social context has a significant impact. Sexual behavior of young people in Ukraine has undergone significant changes and is characterized by irresponsible $\mathrm{d}$ attitude to matters of sex. The average age of first sexual intercourse among adolescents is on average 15,1 years for boys - 14,7 years. The prevalence of premarital sex on the one hand, is a testament to the «liberalization» of sexual attitudes of young people, and on the other actualizes the problem of prevention of unwanted pregnancies and sexually transmitted infections. In the structure of cervical diseases in sexually active adolescent girls the cervical interepithelium neoplasia diagnosed in $25,83 \%$ of patients. Vaccination provides a new opportunity for the primary prevention of cervical cancer and cervical intraepithelial neoplasia. Thus, it is necessary to conduct a proper information campaign for adolescents and their families by involving non-governmental organizations, schools, and health services.

Keywords: PhD, adolescents, human papillomavirus, infections which are passed sexual way, cervical intraepithelial neoplasia, vaccination.

\section{ПІДЛІТКОВИЙ ПЕРІОД: ФАКТОРИ РИЗИКУ ПЕРЕДРАКУ І РАКУ ШИЙКИ МАТКИ ТА МЕТОДИ ЇХ ПРОФІЛАКТИКИ}

Н.К. Сіліна, к. мед. н., старший науковий співробітник відділення медичних та психосоціальних проблем здоров'я сім'ї Інституту педіатрії, акушерства та гінекології НАМН України

Підлітковий вік - це час бурхливого зростання і величезного потенціалу, однак при цьому - і час значних ризиків, коли соціальний контекст має суттєвий вплив. Сексуальна поведінка молоді в Україні зазнала значних змін і характеризується більш розкутим ставленням до питань сексу. Середній вік перших статевих стосунків серед дівчат-підлітків становить 15,1 років, серед хлопчиків - 14,7 років. Поширеність дошлюбних статевих відносин з одного боку є свідченням «лібералізації) сексуальних установок сучасної молоді, а з іншого - актуалізує проблему профілактики небажаної вагітності та передавання під час сексуальних контактів інфекцій, що передаються статевим шляхом. У структурі захворювань шийки матки у сексуально активних дівчат-підлітків дисплазії шийки матки діагностовано у 25,83\% пацієнток. Вакцинопрофілактика дає нову можливість - первинну профілактику дисплазій і раку шийки матки. Таким чином, існує необхідність проведення належної інформаційної кампанії для підлітків та їх сімей з участю громадських організацій, шкіл, служб охорони здоров'я. Ключові слова: підлітки, інфекції передаються статевим шляхом, вірус папіломи людини, дисплазія шийки матки, вакцинопрофілактика.

\section{ПОДРОСТКОВЫЙ ПЕРИОД: ФАКТОРЫ РИСКА ПРЕДРАКА И РАКА ШЕЙКИ МАТКИ И МЕТОДЫ ИХ ПРОФИЛАКТИКИ}

Н.К. Силина, к. мед. н., старший научный сотрудник отделения медицинских и психосоциальных проблем здоровья семьи Института педиатрии, акушерства и гинекологии НАМН Украины

Подростковый возраст - это время бурного роста и огромного потенциала, однако при этом - и время значительных рисков, когда социальный контекст имеет существенное влияние. Сексуальное поведение молодежи в Украине претерпело значительные изменения и характеризуется более раскованным отношением к вопросам секса. Средний возраст первых половых отношений среди девушек-подростков составляет в среднем 15, 1 лет, среди мальчиков - 14,7 лет. Распространенность добрачных половых отношений с одной стороны является свидетельством «либерализации» сексуальных установок современной молодежи, а с другой - актуализирует проблему профилактики нежелательной беременности и передачи во время сексуальных контактов инфекций, передающихся половым путем. В структуре заболеваний шейки матки у сексуально активных девушек-подростков дисплазии шейки матки диагностированы у $25,83 \%$ пациенток. Вакцинопрофилактика дает новую возможность - первичную профилактику дисплазий и рака шейки матки. Таким образом, существует необходимость проведения надлежащей информационной кампании для подростков и их семей сучастием общественных организаций, школ, служб здравоохранения.

Ключевые слова: подростки, инфекции передающиеся половым путём, вирус папилломы человека, дисплазия шейки матки, вакцинопрофилактика. 